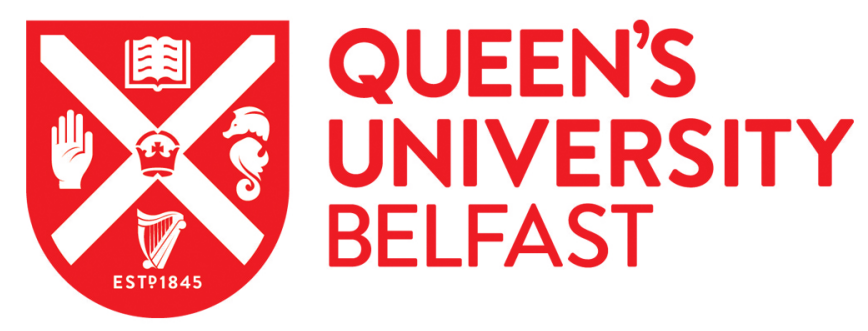

\title{
Transitions from child to adult health care for young people with intellectual disabilities: A systematic review
}

Brown, M., Macarthur, J., Higgins, A., \& Chouliara, Z. (2019). Transitions from child to adult health care for young people with intellectual disabilities: A systematic review: Health transitions and young people with intellectual disabilities. Journal of Advanced Nursing, 1-17. https://doi.org/10.1111/jan.13985, https://doi.org/10.1111/jan.13985

Published in:

Journal of Advanced Nursing

Document Version:

Peer reviewed version

Queen's University Belfast - Research Portal:

Link to publication record in Queen's University Belfast Research Portal

Publisher rights

Copyright 2019 Wiley. This work is made available online in accordance with the publisher's policies. Please refer to any applicable terms of use of the publisher.

\section{General rights}

Copyright for the publications made accessible via the Queen's University Belfast Research Portal is retained by the author(s) and / or other copyright owners and it is a condition of accessing these publications that users recognise and abide by the legal requirements associated with these rights.

Take down policy

The Research Portal is Queen's institutional repository that provides access to Queen's research output. Every effort has been made to ensure that content in the Research Portal does not infringe any person's rights, or applicable UK laws. If you discover content in the Research Portal that you believe breaches copyright or violates any law, please contact openaccess@qub.ac.uk. 
MRS ANNA HIGGINS (Orcid ID : 0000-0002-2821-6618)

Article type : Review

Title page template

- Short informative title

Transitions from child to adult health care for young people with intellectual disabilities: A systematic review

\section{- Short running title}

Transitions to adult health for people with ID

\section{- List of all authors}

BROWN, Michael (PhD, MSc, RN) Professor of Nursing, School of Nursing \& Midwifery, Queen's University, Belfast, Northern Ireland

MACARTHUR, Juliet (PhD, MSc, RN) Chief Nurse Research \& Development, NHS Lothian, Scotland HIGGINS, Anna (MRes, MA) Research Assistant, School of Health \& Social Care, Edinburgh Napier University, Edinburgh, Scotland

CHOULIARA, Zoë (PhD, MSc, PsyDip) Professor of Mental Health, Division in Mental Health \& Counselling, Abertay University, Dundee, Scotland

\section{- Acknowledgments}

\section{- Funding Statement}

This work was supported by the Burdett Trust for Nursing.

This article has been accepted for publication and undergone full peer review but has not been through the copyediting, typesetting, pagination and proofreading process, which may lead to differences between this version and the Version of Record. Please cite this article as doi: 10.1111/jan.13985

This article is protected by copyright. All rights reserved. 
- Conflict of Interest statement

No conflict of interest has been declared by the authors.

- Contact details for the corresponding author

Prof Michael Brown m.j.brown@qub.ac.uk

\section{ABSTRACT}

Aims: To examine the experiences of health transitions for young people with intellectual disabilities and their carers and identify the implications for nursing practice.

Design: A systematic review and critical appraisal of qualitative, quantitative and mixed methods studies.

Data sources: A search of the relevant literature published 2007-2017 was carried out in AMED, ASSIA, CINAHL, MEDLINE, PsycINFO, PubMed and Science Direct Sociological Abstracts databases.

Review Methods: A total of 12 out of 637 papers identified in the search met the inclusion criteria for this review. A narrative review of the papers was undertaken by synthesising the key findings and grouping them into concepts and emergent themes.

Results: Four main themes were identified: (i) becoming an adult; (ii) fragmented transition process and care; (iii) parents as advocates in emotional turmoil; and (iv) making transitions happen.

Conclusion: The range of issues that have an impact on the transition from child to adult health services for young people with intellectual disabilities and their carers raise important implications for policy development, nursing practice and education.

This article is protected by copyright. All rights reserved. 


\section{Impact:}

- What problem did the study address? This review highlights issues, concerns and needs of young people with intellectual disabilities and their carers at the point of transition from paediatric to adult health services.

- What were the main findings? Young people with intellectual disabilities and their carers often have negative experiences of health transitions from paediatric to adult healthcare, with existing services unprepared to respond to their complex and multifaceted health needs.

- Where and on whom will the research have impact? This review has significant implications for health policy and nursing practice by identifying important limitations to existing transition care and making recommendations for policy, nursing practice and nursing education.

Key words: intellectual disabilities, complex needs, transitions, health services, young people, systematic review, nursing

\section{INTRODUCTION}

Many people with intellectual disabilities (ID) present with multiple chronic and complex physical and mental health needs, which may be overlooked and unmet, with significant implications for their health and well-being (Emerson, 2011; Heslop et al., 2014; McCarron et al. 2013). An intellectual disability has be defined by the World Health Organisation (2018) as a significantly reduced ability to understand new or complex information and to learn and apply new skills (impaired intelligence). This results in a reduced ability to cope independently (impaired social functioning) and begins before adulthood, with a lasting effect on development. Due to the complexity of health needs that people with ID experience there is a need for more frequent involvement with health care services when compared with the general population (Hosking et al., 2017). Advances in health care and technology have improved the life expectancy of young people with complex ID (Scottish Government, 2013;

This article is protected by copyright. All rights reserved. 
Matsubasa et al., 2017) and as a result there are increasing numbers of adolescents experiencing transition to adult health and social care services, many with multiple health morbidities (Huang et al., 2016). This systematic review seeks to examine the experiences of health transitions for young people with ID and their carers and to identify their implications for nursing practice. Nurses will be part of multi-professional teams involving health, social care and education who have a combined responsibility for the transition process. It is important to recognise the specific contribution that nurses in a variety of roles can make to enhance the experience of and improve outcomes for young people with ID and their carers.

\section{Background}

In many countries the physical health needs of children and young people with ID are met through mainstream primary care and paediatric services, while their mental health and behavioural needs are addressed in child and adolescent mental health services (Shooshtari et al., 2017). Once an adult, care provision becomes more disparate and is often managed in a range of specialties reflecting specific body system disorders such as respiratory disorders, gastro-intestinal disorders and neurology (Cooper et al., 2015). Reiss et al. (2005) and Davies et al. (2011) highlight different philosophies between paediatric and adult services; characterising the former as family-focussed, providing developmentally-appropriate care with significant parental involvement in decision-making. In contrast, adult services are described as patient-focussed, often requiring autonomous skills, which have an impact on the decision-making process, consent and family involvement for patients with ID.

Transition can be defined as "a purposeful, planned process that addresses the medical, psychosocial and educational/vocational needs of adolescents and young adults with chronic physical and medical conditions as they move from child-centred to adult-oriented health care systems." (Department of Health, 2006: 14).

This article is protected by copyright. All rights reserved. 
Effective transition for young people with ID starts early and demands commitment and support from multi-disciplinary team, including health care professionals who are aware of and responsive to the individual's health and emotional needs and deliver services that are developmentally appropriate (Young-Southward et al., 2017a). Failure to ensure smooth transition can lead to poor experience of adult services, including lack of specialty care, inadequate follow-up, limited access to newer therapies and inferior management of co-morbid conditions (Camfield et al. 2011; Young-Southward et al., 2017a).

Although the need to support young people transitioning from paediatric to adult health services has been acknowledged, many people with ID continue to experience poor transition management. Nurses have previously been suggested as potentially instrumental to transition management and practice development (Betz, 2007; 2013), however research addressing these issues is scarce.

\section{THE REVIEW}

\section{Aims}

The aims of this review were to explore issues related to health care transitions for young people with ID and the policy and nursing practice responses necessary to address their individual and distinct needs. The specific questions addressed were:

1. What are the transition experiences of young people with ID and their families?

2. What are the transition experiences of professionals involved in meeting the health needs of young people with ID and their families?

3. What are the policy and nursing practice responses required to address individual care and support needs at the point of transition from child health to adult health services?

This article is protected by copyright. All rights reserved. 


\section{Design}

\section{Search methods}

The systematic review included empirical studies that adopted quantitative, qualitative or mixed research methods. A subject librarian was consulted to support the literature search process. The databases used were AMED, ASSIA, CINAHL, MEDLINE, PsycINFO, PubMed and Science Direct Sociological Abstracts. Search terms included: transition* AND "intellectual disab*" or "developmental disab*" or "cognitive disab*" or handicap or "learning disab*" or retardation AND health or healthcare or "health care" or care or "health service*" or paediatrics or "children service*" or "adult service*" or nurs*. The papers were published from January 2007 to December 2017. The inclusion criteria were limited to academic journals, peer reviewed empirical studies written in English and included young adults with ID who had transitioned from child into adult health care services. Papers that addressed health transitions for other patient groups, such as those with diabetes and asthma or young adults with a learning difficulty were excluded.

\section{Search outcomes}

The PRISMA process for reporting the results of the searches was used (Moher et al. 2015) (Figure 1). The searches revealed 637 cumulative hits across all the databases. These were screened for relevance and duplicates and 559 were removed. Following review of titles and abstracts, a total of 78 full text articles were assessed against the following eligibility criteria: (i) addressing transition from paediatric to adult health services; and (ii) the sample included individuals with ID. A further 67 papers were excluded and of the excluded papers, the main reasons were that the study sample did not focus exclusively on young people with ID or address transition from child to adult health services. One further paper was identified through hand searching of reference lists, resulting in a total of 12 studies included for full review and synthesis. All included studies were from peer reviewed journals with impact factors ranging from 0.36-5.067 (Table 2).

This article is protected by copyright. All rights reserved. 


\section{Quality appraisal}

The Critical Appraisal Skills Programme (CASP) tools were used as an evidence-based framework to review the papers (Critical Appraisal Skills Programme, 2013). A range of questions were systematically applied to each of the studies (Table 1). Individual questions were scored 0,1 or 2 out of a possible total score of 20 points. A score of 0 was given if the paper contained no information, 1 if there was a limited amount and a score of 2 indicated that the question was fully addressed (Rushbrooke, Murray \& Townsend, 2014). Two members of the research team (MB and JM) independently rated each paper and then compared results and a consensus score was agreed for two where there had been a different result.

Papers demonstrating high quality, with a score of 17 or more, was achieved by eight of the 12 studies (Davis et al., 2011; Barron et al., 2013; Bindels de Heus et al., 2013; Jensen \& Davis 2013; Kuchenbuch et al., 2013; Schultz 2013; Okumura et al., 2015; Young-Southward et al., 2017b). Two studies achieved a moderate score of between 14 and 16 (Woodward et al., 2012; Rehm et al., 2013). Two studies achieved a lower score of 13 or less (Bhaumik et al., 2011; Camfield et al., 2011). The main reasons for these lower quality assessment scores included limited detail regarding the statement of aims, recruitment strategy, ethical considerations, research relationships or the quality of data analysis. Following a rigorous review against the inclusion criteria and the CASP rating by the research team all 12 studies were deemed suitable for inclusion in the final systematic review.

\section{Data abstraction}

The 12 studies that addressed the study aims are detailed in Table 2 . They were undertaken across a range of countries including France $(\mathrm{N}=1)$, Netherlands $(\mathrm{N}=1)$, United Kingdom (UK) $(\mathrm{N}=3)$, Canada $(\mathrm{N}=1)$ and USA $(\mathrm{N}=6)$. The sample sizes ranged from 14-214 participants.

This article is protected by copyright. All rights reserved. 
A total of 7 studies used quantitative methods: cross-sectional design $\mathrm{N}=6$ (Camfield et al., 2011; Woodard et al., 2012; Barron et al., 2013; Bindels-de Heus et al., 2013; Kuchenbuch et al., 2013; Young-Southward et al., 2017b) and longitudinal, observational cohort design N=1 (Jensen and Davis, 2013). Four studies employed qualitative methods: interpretative design N=1 (Davies et al., 2011), ethnography $\mathrm{N}=1$ (Rehm et al., 2012) and grounded theory $\mathrm{N}=2$ (Schultz et al., 2013; Okumura et al., 2015). Mixed methods (cross-sectional and grounded theory approach) were employed in one study (Bhaumik et al., 2011). A range of data collection methods were used including surveys, questionnaires, interviews and validated measures. The latter fell into two main categories; (i) validated measures widely used and recognised in previous research studies; (ii) those developed specifically for use in the particular transitions study.

\section{Synthesis}

It was the initial intention to undertake a meta-analysis of the research studies, however following extraction and critical analysis of the findings this approach was not possible. This was due to the range of designs employed and the different sample sizes. Therefore, a narrative review was undertaken using recognized guidelines and involved a detailed systematic review of the individual papers and synthesis of the key findings (Popay et al. 2006). The findings were grouped into concepts to allow for contrasts and comparisons to be made across and between the themes and studies. The emergent themes were systematically identified across all the studies and coded individually and then as a group by the research team (Caldwell et al. 2011).

\section{RESULTS}

The purpose of this narrative review is to present an analysis of the findings from the existing studies to highlight the experiences of young people with ID and their carers at the point of transition between child and adult health services and emphasise areas for policy and nursing practice development. It was notable in the studies that the role of nurses was not always explicit; however, from the emergent

This article is protected by copyright. All rights reserved. 
themes it has been possible to identify the potential implications for nursing, which are highlighted in the discussion. Four main themes were identified, along with several sub-themes:

1. Becoming an adult: Progression towards self-management, balancing autonomy and parental involvement, changing expectations, capacity and perception of unnatural changes.

2. Fragmented transition process and care: poor preparation and planning, lack of information, lack of lead agency and coordination, unplanned transfer, loss of information, gaps in follow-up, no holistic overview in adult services, falling between the gaps of services, incomplete or delayed transition.

3. Parents as advocates in emotional turmoil: Parents as advocates fighting for services, a maze of information, parents' resourcefulness as the driver for transition, a sense of loss and rejection, fear of the unknown, reluctance to "let go".

4. Making transitions happen: Early initiation and preparation for transition, identifying a lead agency, outlining responsibilities, parent-provider relationships, improved joined and multiagency working, effective information sharing, adequate follow-up, transition coordinator, nursing involvement

\section{Theme 1: Becoming an adult}

How young people with ID are supported to start assuming some responsibility and make decisions about their health care as they transition into adult health services was recognised as requiring extensive planning and support (Bhaumik et al., 2011; Rehm et al., 2012; Schultz 2013; Okumura et al., 2015). Progression towards self-management and balancing autonomy and parental involvement were highlighted as challenging in the context of ID (Rehm et al., 2012; Kuchenbuch et al., 2013). This change of expectations can be an anxious time for both young people and parents, who had been used to being at the centre of the decision-making process (Okumura et al., 2015). Furthermore, transition to adult-oriented health care might feel unnatural to parents of young people with complex

This article is protected by copyright. All rights reserved. 
ID, who will never develop beyond a young child's developmental age and reach autonomy (Bindelsde Heus et al., 2013).

In the US, which operates an insurance-based health service, becoming an adult was seen to have important financial implications for the health care provider, with reports of different total annual charges in paediatric and adult-focused care (Jensen and Davis, 2013) and incentives to retain young people in paediatric services for longer (up to mid-20s) where health insurance policies supported this (Rhem et al., 2012).

\section{Theme 2: Fragmented transition process}

A general sense of dissatisfaction with the transition process was found across the studies included in this review, with an exception of one. Kuchenbuch et al., 2013 found that families of young adults with Dravet syndrome reported a positive experience of transition from paediatric to adult health service with no reported gap in the process. However, this could be because of the study focusing on a single condition of epilepsy, where a clear transition route to adult neurology existed, without consideration for complex co-morbidities. Families frequently reported poor transition preparation, lack of clear information on the process, its commencement and available support (Camfield et al., 2011; Davies et al., 2011; Bindels-de Heus et al., 2013; Schultz et al., 2013). Difficulties with identifying a lead agency and the absence of coordinated, holistic and life-course planning often resulted in poor assessment processes, unmet needs in many areas as well as difficulties with accessing services (Woodward et al., 2012; Bhaumik et al., 2011, Bindels-de Heus et al., 2013; Barron et al., 2013). There was also little evidence of multiagency and joint working considering a wider spectrum of needs including employment, day activities and social opportunities (Rehm et al., 2012, Bindels-de Heus et al., 2013).

In contrast to a planned transition, the 'transfer' to adult health care was often sparked by a crisis or 'ageing out' of the system due to the terms of insurance policies (Schultz, 2013; Camfield et al., 2011). In turn, this carried a risk of essential medical history and information being lost, resulting in

This article is protected by copyright. All rights reserved. 
inappropriate management of medical conditions at the point of transition and beyond (Woodard et al., 2013; Young-Southward et al., 2017b). In some cases, significant gaps in ongoing follow-up after the last paediatric appointment did occur (Davies et al., 2011; Kuchenbuch et al. 2013), resulting in young people and their families turning to emergency departments for care (Davies et al., 2011). An incomplete or delayed transition to adult services was also common (Rehm et al., 2012; Bindel-de Heus et al., 2013) and associated with the need for reinstatement of specialist input by paediatric services (Jensen and Davis, 2013) or difficulties in finding equivalent adult physicians willing to care for severely disabled and complex patients (Camfield et al., 2011).

Lack of a paediatrician-like, holistic role in adult services and separation of care into individual specialties across hospital sites (Camfield et al., 2011; Bindels-de Heus et al., 2013) often placed the responsibility of co-ordinating assessments, treatments and reviews of the young person's health needs on the general practitioner. As they tend to have limited involvement with the individual during their childhood and adolescence (Schultz et al., 2013) and often lack awareness of the health needs of people with ID (Bhaumik et al., 2011), this resulted in a sense for families of 'falling between the gaps' of services (Davies et al., 2011). In some areas medical care was provided by psychiatrists with a specific focus on mental health, which left some young people without general medical involvement beyond primary care (Young-Southward et al., 2017b).

\section{Theme 3: Parents as advocates in emotional turmoil}

The uncoordinated, poorly planned and inconsistent transition process often forced parents to take on a role of advocates and guardians, with a deep sense of having to 'fight' for appropriate care in adult services (Schultz, 2013; Okumura et al., 2015). Parents acted as 'information gatherers' navigating a maze of absent, incorrect or conflicting information, leading to a sense of frustration and confusion created by uncoordinated agencies and lack of transparency regarding available resources (Schultz, 2013; Okumura et al., 2015; Bhaumik et al., 2011). When appropriate processes were not in place, or

This article is protected by copyright. All rights reserved. 
discontinuity between services occurred, transition was often facilitated by parents' resourcefulness, family support and ability to establish new relationships in the adult health care setting (Davies et al., 2011).

Several studies highlighted the emotional impact of transition, which was often described as a sense of loss, abandonment or rejection by health care professionals and having to 'let go' of trusting relationships with professionals and services (Bhaumik et al., 2011; Davies et al, 2011; Schultz 2013; Young-Sutherland et al., 2017b; Camfield et al., 2011; Bindels de- Heus et al., 2013). Families rarely felt ready to move to adult-oriented health systems and entered the transition period with little or no information, which created uncertainty with regards to the process, future care and source of medical insurance (Camfield et al., 2011; Davies et al., 2011; Rehm et al., 2012; Bhaumik et al., 2011). A fear of the unknown, losing services and having to build a new network of support with professionals was often expressed (Bhaumik et al., 2011; Davies et al., 2011; Schultz, 2013).

These feelings were sometimes further reinforced by stories of poor transition experiences of other families and a desire to remain in child service was often expressed to avoid what was viewed as leading to potentially poorer health outcomes and loss of much needed support (Camfield et al., 2011; Davies et al., 2011; Woodward et al., 2012; Bindels-de Heus et al., 2013; Jensen \& Davis 2013; Kuchenbach et al., 2013).

\section{Theme 4: Making transitions happen}

The reviewed studies highlighted transition as a multidimensional, multiagency process which needs to address all areas of adult functioning and account for interactions between multiple sectors in the environment (Bhaumik et al., 2011; Schultz, 2013). Recommendations for effective transition included early initiation of the process (Davies et al., 2011; Bindels-de Heus et al., 2013; Bhaumik et al., 2011) and identifying a lead agency to ensure that policies,

This article is protected by copyright. All rights reserved. 
procedures and care pathways that account for the often-complex health needs of young adults with ID are in place (Camfield et al., 2011; Davies et al., 2011; Barron et al., 2013). Quality of transition preparation was considered paramount to the individual and family's experience (Kuchenbuch et al., 2013) and should include a robust assessment of needs (Barron et al., 2012), including legal requirements such as advance care planning, health care power of attorney and guardianship (Woodward et al., 2012).

There were calls for clear definition of responsibilities for each professional, improved provision of written information and education for young people and their families (Camfield et al., 2011) and the identification of a key professional to coordinate the process (Davies et al., Bhaumik et al. 2011). The role of a transition coordinator was seen as beneficial in ensuring that care needs were met, essential information communicated, and a formal handover of care undertaken (Bindels-de Heus et al., 2013). The coordinator often took on an advocacy role and was seen as an important bridge between the young person, their family and all agencies involved (Davies et al., 2011; Rhem et al., 2012; Bhaumik et al., 2011; Okumura et al., 2015).

Better working relationships between child and adult health services, for instance through joint transition clinics could aid the development of standards of care or transition care pathways (Camfield et al., 2011), promote effective coordination and information sharing (Bindels-de Heus et al., 2013; Kuchenbuch et al., 2013) as well as help alleviate patient and family anxiety and clinician's concerns about the quality of adult health care (Camfield et al., 2011).

This article is protected by copyright. All rights reserved. 
Adequate follow-up and ongoing involvement of paediatricians after transition was considered helpful and influenced overall satisfaction with the transitions process along with the stability of the health conditions experienced by the young adult (Kuchenbuch et al., 2013, Bindels-de Heus et al., 2013). Determining transition outcomes measure was seen as necessary for addressing individual needs and assessing the effectiveness of the process (Bhaumik et al., 2011; Barron et al., 2013).

Family and patient-centred approach to transition and service provision, with strong parentprovider relationships and acknowledgement of parental expertise through their involvement in decision-making process were viewed as important for enabling transition for people with ID (Bindels-de Heus et al., 2013; Schultz, 2013). Providing parents access to transparent and accurate information, including the young person's medical records (Schultz, 2013) and assistance to navigate and manage available resources (Okumura et al., 2015) could help use parents' networking and advocacy skills as well as improve their satisfaction with the transition process (Bhaumik et al., 2011; Bindels-de Heus et al., 2013).

Nurses were highlighted as having the potential to play an instrumental role in transition planning and implementation due to their holistic, life-course perspective that includes family and wider psychosocial needs of the individual (Schultz, 2013; Rehm et al., 2012). Acting as care providers, coordinators and consultants for young people with chronic health and developmental conditions, they were often seen as best suited to address unmet needs (Rehm et al., 2012; Woodward et al., 2012). Nurses were recognised for their expert knowledge (Davies et al., 2011) and ability to easily adopt new tools and clinical guidelines to assist young people with ID and their families to undertake planning of transition and future care

This article is protected by copyright. All rights reserved. 
(Rehm et al., 2012). They were also seen as well situated to develop and implement a transition program that acknowledges the interrelationship between the individual, their family and the environment (Schultz, 2013).

\section{DISCUSSION}

Cohen et al. (2011) describe children with medical complexities as 'an emerging population' whose needs are not easily met by existing health care models. Advances in health care have significantly improved life expectancy leading to increasing numbers of people with complex intellectual and developmental disabilities moving through childhood, adolescence and into adulthood (Ryan et al., 2014; Jajour 2015).

This review reveals that current services are often ill-prepared to respond to these multifaceted health needs of young people with ID at the point of transition from paediatric to adult health care (HughesMcCormack et al., 2018). The findings are in keeping with wider evidence pointing to poor experience of health transitions for young people with a range of chronic conditions (Heery et al., 2015; Sheehan et al., 2015; Singh and Tuomainen, 2015; Solanke et al., 2018) and a lack of research to evaluate focussed interventions (Campbell et al., 2016).

The findings of this review can be interpreted within the framework of the middle-range Transition Theory (Meleis et al., 2000), which recognises transitions as complex processes occurring simultaneously in multiple dimensions. It highlights transition as core to nursing practice, with nurses acting as the primary caregivers acting as facilitators at this vulnerable time. Consistent with the Transition Theory framework (Meleis et al., 2000), this review reiterates the importance of awareness, engagement, adapting to change and difference, time span and critical points and events as being core properties of health transitions from paediatric to adult health services. Knowledge of the transition process was seen to influence both the carers' and healthcare professionals' level of engagement and

This article is protected by copyright. All rights reserved. 
carers' unmet or divergent expectations towards the adult health system, which had an impact on their ability to adapt to the new environment. Anticipation, distress and confusion are characteristic signs that precede stability and nurses are in a position to provide critical input, knowledge and experience to facilitate the transition milestones. Furthermore, personal, community and societal conditions such as the carers' ability to act as an advocate or access to information and support is seen to further facilitate or inhibit the transition process and health outcomes (Meleis et al., 2000). The implications and relevance of the findings of this review for nursing are considered from policy, practice and educational perspectives along with recommendations for future research.

\section{Policy}

The specific needs of young people with an ID and their families and carers during transition must be acknowledged at a strategic level through inter-agency policy development recognising the interrelationships between health, education and social services. Such policy should be informed by existing quality standards and models that focus on processes to embed a co-ordinated approach to planning, centred on clear identification of roles and responsibilities of each agency and key professionals. Examples include:

- five core elements to transition planning recommended by the UK National Institute for Health and Care Excellence (NICE) (2016): planning transition, annual meeting, named worker, introduction to adult services and missed appointments after transition to adult services.

- a model with six core principles from the US organisation 'Got Transition' (2014): i) transition policy, ii) transition tracking and monitoring, iii) transition readiness, iv) transition planning, v) transfer of care, vi) transfer completion.

This article is protected by copyright. All rights reserved. 
Both approaches mirror recommendations from this review in relation to early initiation of the transition process (Davies et al., 2011; Bindels-de Heus et al., 2013; Bhaumik et al., 2011), identifying lead professionals (Camfield et al., 2011; Davies et al., 2011; Barron et al., 2013, Bhaumik et al., 2011) and post transition follow-up (Kuchenbuch et al., 2013, Bindels-de Heus et al., 2013)

Policy should support efficient, timely, gradual approaches to transition, based on person-centred, needs-led services that promote continuity. The role of family carers during transition planning and processes must also be addressed (Aldiss et al., 2015), including the potential of parent-led peer support groups acting as an information point with regards to options and resources in adult health services (Kingsnorth et al., 2011). This supports the Transition Theory's outcome indicators of "feeling connected" to the community, reliable information and knowledgeable and supportive healthcare professionals (Meleis et al., 2000).

\section{Nursing Practice}

The review revealed numerous examples of separate and compartmentalised adult and child services, which hindered the health transitions of young people (Davies et al., 2011). Operating in silos could be counterbalanced by the development and application of shared models of practice and integrated care pathways from paediatric services to adult health care settings (Young-Southward et al., 2017a). Nurses were often identified in the research studies as playing an instrumental role in both the development and implementation of these kinds of approaches (Woodward et al., 2012; Schultz, 2013, Rehm et al, 2012). However, Betz (2013) argues that nurses in paediatric and adult services need to raise their profile and collaborate more fully with interdisciplinary colleagues to help shape the best quality transition practices for people with ID. Joint paediatric and adult transition clinics, involving specialist nurses, could be a way to share skills and information as well as relieve parents' anxieties regarding the move to an adult-oriented health care (Camfield and Camfield, 2011; Crowley et al., 2011)

This article is protected by copyright. All rights reserved. 
There is also a need to understand and evaluate the contribution of nursing roles that sit outside mainstream paediatric and adult nursing. School nurses have specialist graduate level education in community health and the health needs of school-aged children and young people (Royal College of Nursing, 2017) and exist in many countries in North America, Europe, Asia and Australasia (Maughan, 2016). They are increasingly recognised as having a crucial role in care co-ordination and planning for children with complex needs (McClanahan and Weismuller, 2015) and should be integral to transition planning. Whilst there have been examples of nurses with specialist qualifications in ID being appointed in the US to transition co-ordinator posts (Betz and Redcay, 2005) such roles often project based and not sustained. Many UK health services are implementing the role of intellectual disability liaison nurses as a way of operationalising person-centred health care in general hospital settings (Castles et al., 2015; MacArthur et al., 2015;). This role is recognised as contributing to family support, more effective communication between services and individual clinicians, proactive care as well as enabling inclusive decision-making and appropriate levels of autonomy (Brown et al., 2016). There are lessons to be learned from this type of liaison role that could be applied more comprehensively where specialist nurses are instrumental to transition planning.

\section{Nurse Education}

The recommendations emerging from this review have implications for pre and post registration education of all nurses, both in terms of raising awareness of the unique health needs of young people with ID and the potential for deterioration in some health outcomes and negative experiences at the transitions of health care (Young-Southward et al., 2017a). According to the Transition Theory, raising awareness of transition and associated issues are paramount to healthy transition outcomes (Meleis et al., 2000). There is recognition of the importance of developing meaningful learning approaches for undergraduate nurses (Trollor et al., 2018), particularly where this involves direct contact with people with ID. In the UK the recently published proficiency standards for registered nurses (Nursing and Midwifery Council, 2018) emphasise the leadership role for nurses in coordinating and managing the complex nursing and integrated care needs of people at any stage of

This article is protected by copyright. All rights reserved. 
their lives, across a range of organisations and settings. Curriculum planning, teaching and practice competencies based on these standards will need to include the principles of partnership, collaboration and interagency working, all of which have been highlighted in this review as key components of transition planning. Focussing on the health needs of young people with an ID at the time of transition must be central to both theory and practice elements of undergraduate education of all nurses, given their likely involvement in care of such individuals in a wide range of specialties and care settings.

In addition to highlighting essential components for undergraduate nursing education, this review identifies important professional and ethical issues for inclusion in continuing professional development programmes for all nurses. These include communication and legal issues related to capacity and consent (Sowney \& Barr, 2007), the need for reasonable adjustments to support shared decision-making and meet specific health needs (Tuffrey-Wijney, 2014; MacArthur et al., 2015) and the concept of family-centred care (Coyne, 2015).

\section{Limitations}

There are several limitations of this review, reflecting methodological issues and gaps in the existing literature. Due to a wide range of designs and mainly qualitative or mixed-methods employed by the studies, a meta-analysis was not possible; a systematic narrative synthesis was conducted. The full extent of nursing involvement in the transition process was difficult to assess due to the variety of research questions of the individual studies. This review focused primarily on health transitions, however several the studies also explored experiences of other transitions occurring simultaneously, including moving to adult social care services or accommodation and these have not been explicitly integrated in this review. Although the reviewed studies were conducted in several different countries, with divergent health and health insurance systems, the primary findings and recommendations appear to be generalisable and transferable to nursing practice in different healthcare settings in the UK and internationally.

This article is protected by copyright. All rights reserved. 


\section{CONCLUSION}

The findings of this review highlight that transition from paediatric to adult health services is a vulnerable time for both individuals with ID and their families and carers, who continue to have multiple, complex needs. These are often left unrecognised and unmet by existing services, which are often ill-prepared to respond to the increasing life expectancy and medical complexity of this population of young adults. Parents often take on roles of advocates, while experiencing emotional turmoil and have limited access to reliable information and support. This review reveals that nurses can play a significant role at the time of transition and beyond in ensuring that the transition process is managed in a more person-centred and family-centred manner and thus limit the negative impact on health and wellbeing of people with ID and their carers. Changes at the policy, nursing practice and education levels are needed to ensure an improvement to transition experiences.

Further research is required to further identify nursing contributions, best practice and education needs in relation to transition from child to adult health services for young people with ID. Transition intervention and outcome studies, considering experiences, health and wellbeing of both carers and people with ID are also limited and require further research input.

\section{Conflict of Interest statement}

No conflict of interest has been declared by the authors.

\section{Author Contributions:}

All authors have agreed on the final version and meet at least one of the following criteria (recommended by the ICMJE*):

1) substantial contributions to conception and design, acquisition of data, or analysis and interpretation of data;

This article is protected by copyright. All rights reserved. 
2) drafting the article or revising it critically for important intellectual content.

* http://www.icmje.org/recommendations/

\section{References}

Aldiss, S., Ellis, J., Cass, H., Pettigrew, T., Rose, L. \& Gibson, F., (2015). Transition from child to adult care - 'It's Not a One-Off Event': Development of benchmarks to improve the experience. Journal of Pediatric Nursing, 30(5)638-647. https://doi.org/10.1016/j.pedn.2015.05.020

Barron, D. A., Molosankwe, I., Romeo, R., \& Hassiotis, A. (2013). Urban adolescents with intellectual disability and challenging behaviour: costs and characteristics during transition to adult services. Health \& social care in the community, 21(3), 283-292. doi: 10.1111/hsc.12015

Bhaumik, S., Watson, J., Barrett, M., Raju, B., Burton, T., \& Forte, J. (2011). Transition for teenagers with intellectual disability: carers' perspectives. Journal of Policy and Practice in Intellectual Disabilities, 8(1), 53-61. https://doi.org/10.1111/hsc.12015

Betz, C.L. (2007). Facilitating the transition of adolescents with developmental disabilities: nursing practice issues and care. Journal of Pediatric Nursing, 22(2); 103-115.

https://doi.org/10.1016/j.pedn.2006.07.006

Betz, C.L. (2013). Health care transition for adolescents with special healthcare needs: Where is nursing? Nursing outlook, 61(5), 258-265. https://doi.org/10.1016/j.outlook.2012.08.009

This article is protected by copyright. All rights reserved. 
Betz, C.L. \& Redcay, G. (2005). Dimensions of the transition service coordination role. Journal of specialists in pediatric nursing, 10(2), 49-59. https://doi.org/10.1111/j.1744-6155.2005.00010.x

Bindels-de Heus, K. G., van Staa, A., van Vliet, I., Ewals, F. V., \& Hilberink, S. R. (2013). Transferring young people with profound intellectual and multiple disabilities from pediatric to adult medical care: parents' experiences and recommendations. Intellectual and developmental disabilities, 51(3), 176-189.

https://doi.org/10.1352/1934-9556-51.3.176

Brown, M., Chouliara, Z., MacArthur, J., McKechanie, A., Mack, S., Hayes, M., \& Fletcher, J. (2016). The perspectives of stakeholders of intellectual disability liaison nurses: a model of compassionate, person- centred care. Journal of Clinical Nursing, 25(7-8), 972-82. https://doi.org/10.1111/jocn.13142

Caldwell, K., Henshaw, L. and Taylor, G., (2011). Developing a framework for critiquing health research: an early evaluation. Nurse Education Today, 31(8), e1-e7.

https://doi.org/10.1016/j.nedt.2010.11.025

Camfield, P., \& Camfield, C. (2011). Transition t adult care for children with chronic neurological disorders. Annals of Neurology, 69(3), 437-44. https://doi.org/10.1002/ana.22393

Camfield, P. R., Gibson, P. A., \& Douglass, L. M. (2011). Strategies for transitioning to adult care for youth with Lennox- Gastaut syndrome and related disorders. Epilepsia, 52, 21-27. https://doi.org/10.1111/j.1528-1167.2011.03179.x

This article is protected by copyright. All rights reserved. 
Campbell, F., Biggs, K., Aldiss, S.K., O'Neill, P.M., Clowes, M., McDonagh, J., While, A. and Gibson, F., (2016). Transition of care for adolescents from paediatric services to adult health services. The Cochrane Database of Systematic Reviews, 4, doi: 10.1002/14651858.CD009794.pub2.

Castles, A., Bailey, C., Gates, B. and Sooben, R., (2014). Experiences of the implementation of a learning disability nursing liaison service within an acute hospital setting: a service evaluation. British Journal of Learning Disabilities, 42(4), 272-281 https://doi.org/10.1111/bld.12070

Cohen, E., Kuo, D.Z., Agrawal, R., Berry, J.G., Bhagat, S.K., Simon, T.D., Srivastava, R., (2011). Children with medical complexity: an emerging population for clinical and research initiatives. Pediatrics, peds-2010. doi: 10.1542/peds.2010-0910

Cooper, S. A., McLean, G., Guthrie, B., McConnachie, A., Mercer, S., Sullivan, F., \& Morrison, J. (2015). Multiple physical and mental health comorbidity in adults with intellectual disabilities: population-based cross-sectional analysis. BMC family practice, 16(1), 110. https://doi.org/10.1186/s12875-015-0329-3

Coyne, I. (2015). Families and health- care professionals' perspectives and expectations of family- centred care: hidden expectations and unclear roles. Health expectations, 18(5), 796-808. https://doi.org/10.1111/hex.12104

Crowley, R., Wolfe, I., Lock, K., McKee, M., (2011). Improving the transition between paediatric and adult healthcare: a systematic review. Archives of disease in childhood, 96(6), 548-553. http://dx.doi.org/10.1136/adc.2010.202473

This article is protected by copyright. All rights reserved. 
Davies, H., Rennick, J., \& Majnemer, A. (2011). Transition from pediatric to adult health care for young adults with neurological disorders: Parental perspectives. Canadian journal of neuroscience nursing, 33(2), 32-39.

Department of Health/Child Health and Maternity Services Branch (2006). Transition:

getting it right for young people. Improving the transition of young people with long term conditions from children's to adult health services. London: Department of Health https://webarchive.nationalarchives.gov.uk/20130123205838/http://www.dh.gov.uk/en/Publicationsan dstatistics/Publications/PublicationsPolicyAndGuidance/DH_4132145 [accessed 17 December 2018]

Emerson, E. (2011). Health status and health risks of the "hidden majority" of adults with intellectual disability. Intellectual and developmental disabilities, 49(3), 155-165. https://doi.org/10.1352/19349556-49.3.155

Got Transition (2014) Six Core Elements of Health Care Transition 2.0 Integrating Young Adults into Adult Health Care for use by Internal Medicine, Family Medicine and Med-Peds Providers https://www.gottransition.org/resourceGet.cfm?id=212 [accessed 27 July 2018]

Heery, E., Sheehan, A.M., While, A.E., Coyne, I., (2015). Experiences and outcomes of transition from pediatric to adult health care services for young people with congenital heart disease: a systematic review. Congenital heart disease, 10(5),413-427. https://doi.org/10.1111/chd.12251

Heslop, P., Blair, P. S., Fleming, P., Hoghton, M., Marriott, A., \& Russ, L. (2014). The Confidential Inquiry into premature deaths of people with intellectual disabilities in the UK: a population-based study. The Lancet, 383(9920), 889-895. https://doi.org/10.1016/S0140-6736(13)62026-7

This article is protected by copyright. All rights reserved. 
Hosking, F.J., Carey, I.M., DeWilde, S., Harris, T., Beighton, C. and Cook, D.G., 2017. Preventable emergency hospital admissions among adults with intellectual disability in England. The Annals of Family Medicine, 15(5), pp.462-470. http://doi:10.1370/afm.2104

Huang, J., Zhu, T., Qu, Y., \& Mu, D. (2016). Prenatal, perinatal and neonatal risk factors for intellectual disability: A systemic review and Meta-Analysis. PloS One, 11 (4), e0153655. https://doi.org/10.1371/journal.pone.0153655

Hughes-McCormack, L.A., Rydzewska, E., Henderson, A., MacIntyre, C., Rintoul, J., Cooper, S.A., (2018). Prevalence and general health status of people with intellectual disabilities in Scotland: a total population study. J Epidemiol Community Health, 72(1), 78-85. http://dx.doi.org/10.1136/jech-2017209748

Jarjour, I. T. (2015). Neurodevelopmental outcome after extreme prematurity: A review of the literature. Pediatric neurology, 52(2), 143-152. https://doi.org/10.1016/j.pediatrneurol.2014.10.027

Jensen, K. M., \& Davis, M. M. (2013). Health care in adults with Down syndrome: a longitudinal cohort study. Journal of Intellectual Disability Research, 57(10), 947-958.

https://doi.org/10.1111/j.1365-2788.2012.01589.x

Kingsnorth, S., Gall, C., Beayni, S. and Rigby, P., (2011). Parents as transition experts? Qualitative findings from a pilot parent- led peer support group. Child: care, health and development, 37(6), 833840. https://doi.org/10.1111/j.1365-2214.2011.01294.x

This article is protected by copyright. All rights reserved. 
Kuchenbuch, M., Chemaly, N., Chiron, C., Dulac, O., \& Nabbout, R. (2013). Transition and transfer from pediatric to adult health care in epilepsy: a families' survey on Dravet syndrome. Epilepsy \& Behavior, 29(1), 161-165. https://doi.org/10.1016/j.yebeh.2013.07.015

MacArthur, J., Brown, M., McKechanie, A., Mack, S., Hayes, M., Fletcher, J., (2015). Making reasonable and achievable adjustments: the contributions of learning disability liaison nurses in 'Getting it right' for people with learning disabilities receiving general hospitals care. Journal of Advanced Nursing, 71(7),1552-1563. https://doi.org/10.1111/jan.12629

Matsubasa, T., Mitsubuchi, H., Kimura, A., Shinohara, M., \& Endo, F. (2017). Medically dependent severe motor and intellectual disabilities: Time study of medical care. Pediatrics International, 59(6), 714-719. https://doi.org/10.1111/ped.13256

Maughan, E. D. (2016) School nursing around the world: Results of an international survey. CNA Webinar Series: Progress in Practice https://canadian-nurse.com/ /media/cna/pagecontent/pdf-en/school-nursing-around-the-world_results-of-an-international-survey.pdf?la=en [Accessed 13 December 2018]

McCarron, M., Swinburne, J., Burke, E., McGlinchey, E., Carroll, R., \& McCallion, P. (2013). Patterns of multimorbidity in an older population of persons with an intellectual disability: results from the intellectual disability supplement to the Irish longitudinal study on aging (IDSTILDA). Research in developmental disabilities, 34(1), 521-527. https://doi.org/10.1016/j.ridd.2012.07.029

This article is protected by copyright. All rights reserved. 
McClanahan, R. \& Weismuller, P.C., (2015). School nurses and care coordination for children with complex needs: An integrative review. The Journal of School Nursing, 31(1), 34-43.

https://doi.org/10.1177/1059840514550484

Meleis, A. I., Sawyer, L. M., Im, E., Hilfinger Messias, D. K., \& Schumacher, K. (2000).

Experiencing transitions: An emerging middlerange theory. Advances in Nursing Science, 23, 12-28. http://dx.doi.org/10.1097/00012272-200009000-00006

Moher, D., Shamseer, L., Clarke, M., Ghersi, D., Liberati, A., Petticrew, M., Shekelle, P. \& Stewart, L. A. (2015). Preferred reporting items for systematic review and meta-analysis protocols (PRISMAP) 2015 statement. Systematic reviews, 4(1), 1. https://doi.org/10.1186/2046-4053-4-1

National Institute for Health and Care Excellence (2016) Transition from children's to adults' services https://www.nice.org.uk/guidance/qs140 [accessed 27 July 2018]

Nursing and Midwifery Council (2018) Standards of proficiency for registered nurses. https://www.nmc.org.uk/globalassets/sitedocuments/education-standards/future-nurseproficiencies.pdf [Accessed 27 July 2018]

Okumura, M. J., Saunders, M., \& Rehm, R. S. (2015). The role of health advocacy in transitions from pediatric to adult care for children with special health care needs: bridging families, provider and community services. Journal of pediatric nursing, 30(5), 714-723.

https://doi.org/10.1016/j.pedn.2015.05.015

This article is protected by copyright. All rights reserved. 
Popay, J., Roberts, H.M., Snowden, A., Petticrew, M., Arai, L., Rodgers, M., Britten N. (2006)

Guidance on the conduct of narrative synthesis in systematic reviews. London: Institute for Health Research.

Reiss, J. G., Gibson, R. W., \& Walker, L. R. (2005). Health care transition: youth, family and provider perspectives. Pediatrics, 115(1), 112-120. doi: 10.1542/peds.2004-1321

Rehm, R. S., Fuentes-Afflick, E., Fisher, L. T., \& Chesla, C. A. (2012). Parent and youth priorities during the transition to adulthood for youth with special health care needs and developmental disability. ANS. Advances in nursing science, 35(3), E57. http://doi:10.1097/ANS.0b013e3182626180

Royal College of Nursing (2017) An RCN Toolkit for School Nurses https://www.rcn.org.uk//media/royal-college-of-nursing/.../2017/.../pub-006316.pdf [Accessed 13 December 2018]

Rushbrooke, E., Murray, C. D., \& Townsend, S. (2014). What difficulties are experienced by caregivers in relation to the sexuality of people with intellectual disabilities? A qualitative metasynthesis. Research in developmental disabilities, 35(4), 871-886.

https://doi.org/10.1016/j.ridd.2014.01.012

Ryan, A., Taggart, L., Truesdale-Kennedy, M., \& Slevin, E. (2014). Issues in caregiving for older people with intellectual disabilities and their ageing family carers: a review and commentary. International journal of older people nursing, 9(3), 2017-226. https://doi.org/10.1111/opn.12021

This article is protected by copyright. All rights reserved. 
Schultz, R. J. (2013). Parental experiences transitioning their adolescent with epilepsy and cognitive impairments to adult health care. Journal of Pediatric Health Care, 27(5), 359-366.

https://doi.org/10.1016/j.pedhc.2012.03.004

Scottish Government. (2013). The keys to life: improving quality of life for people with learning disabilities. Edinburgh: Scottish Government.

Sheehan, A.M., While, A.E., Coyne, I., (2015). The experiences and impact of transition from child to adult healthcare services for young people with Type 1 diabetes: a systematic review. Diabetic Medicine, 32(4), 440-458. https://doi.org/10.1111/dme.12639

Shooshtari, S., Brownell, M., Mills, R.S., Dik, N., Yu, D.C., Chateau, D., Burchill, C.A. \&Wetzel, M. (2017). Comparing Health Status, Health Trajectories and Use of Health and Social Services between Children with and without Developmental Disabilities: A Population- based Longitudinal Study in Manitoba. Journal of Applied Research in Intellectual Disabilities, 30(4), 584-601. https://doi.org/10.1111/jar.12253

Singh, S.P. \& Tuomainen, H., (2015). Transition from child to adult mental health services: needs, barriers, experiences and new models of care. World Psychiatry, 14(3), 358-361. https://doi.org/10.1002/wps.20266

Solanke, F., Colver, A., McConachie, H. \& Transition Collaborative Group (2018). Are the health needs of young people with cerebral palsy met during transition from child to adult health care?. Child: care, health and development, 44(3), 355-363. https://doi.org/10.1111/cch.12549

This article is protected by copyright. All rights reserved. 
Sowney, M., \& Barr, O. (2007). The challenges for nurses communicating with and gaining valid consent from adults with intellectual disabilities within the accident and emergency care service. Journal of Clinical Nursing, 16(9), 1678-1686. https://doi.org/10.1111/j.13652702.2006.01642.x

Trollor, J.N., Eagleson, C., Turner, B., Salomon, C., Cashin, A., Iacono, T., Goddard, L. \& Lennox, N., (2018). Intellectual disability content within pre-registration nursing curriculum: How is it taught?. Nurse Education Today. 69, 48-52. https://doi.org/10.1016/j.nedt.2018.07.002

Tuffrey-Wijne, I., Goulding, L., Giatras, N., Abraham, E., Gillard, S., White, S., Edwards, C., Hollins, S., (2014). The barriers to and enablers of providing reasonably adjusted health services to people with intellectual disabilities in acute hospitals: evidence from a mixed-methods study. $B M J$ open, 4(4), e004606. http://dx.doi.org/10.1136/bmjopen-2013-004606

Woodward, J. F., Swigonski, N. L., \& Ciccarelli, M. R. (2012). Assessing the health, functional characteristics and health needs of youth attending a noncategorical transition support program. Journal of adolescent health, 51(3), 272-278.

https://doi.org/10.1016/j.jadohealth.2011.12.016

World Health Organisation (2018) Definition: intellectual disability. http://www.euro.who.int/en/health-topics/noncommunicable-diseases/mentalhealth/news/news/2010/15/childrens-right-to-family-life/definition-intellectual-disability [Accessed 13 December 2018]

This article is protected by copyright. All rights reserved. 
Young- Southward, G., Philo, C., \& Cooper, S. A. (2017a). What Effect Does Transition Have on Health and Well- Being in Young People with Intellectual Disabilities? A Systematic

Review. Journal of Applied Research in Intellectual Disabilities, 30(5), 805-823. https://doi.org/10.1111/jar.12286

Young- Southward, G., Rydzewska, E., Philo, C., \& Cooper, S. A. (2017b) Physical and mental health of young people with and without intellectual disabilities: cross-sectional analysis of a whole country population. Journal of Intellectual Disability Research, 61(10), 984-993. doi: 10.1111/jir.12422.

This article is protected by copyright. All rights reserved. 
Table 1: CASP scores

\begin{tabular}{|c|c|c|c|c|c|c|c|c|c|c|c|c|}
\hline CASP criteria & $\begin{array}{l}\text { Bhaumik et } \\
\text { al. } \\
\text { (2011) }\end{array}$ & $\begin{array}{l}\text { Camfield et } \\
\text { al. } \\
\text { (2011) }\end{array}$ & $\begin{array}{l}\text { Davies et } \\
\text { al. } \\
\text { (2011) }\end{array}$ & $\begin{array}{l}\text { Woodard et } \\
\text { al. } \\
\text { (2012) }\end{array}$ & $\begin{array}{l}\text { Rehm et } \\
\text { al. } \\
\text { (2012) }\end{array}$ & $\begin{array}{l}\text { Barron et } \\
\text { al. } \\
(2013)\end{array}$ & $\begin{array}{l}\text { Bindels-de } \\
\text { Heus et al. } \\
\text { (2013) }\end{array}$ & $\begin{array}{l}\text { Jensen \& } \\
\text { Davis } \\
\text { (2013) }\end{array}$ & $\begin{array}{l}\text { Kuchenbuch et } \\
\text { al. (2013) }\end{array}$ & $\begin{array}{l}\text { Schultz } \\
\text { (2013) }\end{array}$ & $\begin{array}{l}\text { Okumura et } \\
\text { al. } \\
\text { (2015) }\end{array}$ & $\begin{array}{l}\text { Young-Southward et } \\
\text { al. (2017) }\end{array}$ \\
\hline $\begin{array}{l}\text { 1. Clear statement } \\
\text { of aims }\end{array}$ & 2 & 1 & 2 & 2 & 1 & 2 & 2 & 2 & 2 & 2 & 2 & 2 \\
\hline $\begin{array}{l}\text { 2. Appropriate } \\
\text { methodology }\end{array}$ & 2 & 1 & 2 & 2 & 2 & 2 & 2 & 2 & 2 & 2 & 2 & 2 \\
\hline $\begin{array}{l}\text { 3. Appropriate } \\
\text { research design }\end{array}$ & 2 & 2 & 2 & 2 & 2 & 2 & 2 & 2 & 2 & 2 & 2 & 2 \\
\hline $\begin{array}{l}\text { 4. Appropriate } \\
\text { recruitment } \\
\text { strategy }\end{array}$ & 2 & 2 & 2 & 1 & 1 & 1 & 2 & 2 & 2 & 2 & 1 & 2 \\
\hline $\begin{array}{l}\text { 5. Appropriate } \\
\text { data collection } \\
\text { methods }\end{array}$ & 2 & 2 & 2 & 2 & 2 & 2 & 2 & 2 & 2 & 2 & 2 & 2 \\
\hline $\begin{array}{l}\text { 6. Research } \\
\text { relationships } \\
\text { considered }\end{array}$ & 0 & 0 & 1 & 0 & 0 & 0 & 0 & 0 & 0 & 0 & 0 & 0 \\
\hline $\begin{array}{l}\text { 7. Consider } \\
\text { ethical issues }\end{array}$ & 0 & 0 & 2 & 0 & 2 & 2 & 2 & 2 & 2 & 2 & 2 & 2 \\
\hline $\begin{array}{l}\text { 8. Rigorous } \\
\text { analysis }\end{array}$ & 2 & 1 & 2 & 2 & 2 & 2 & 2 & 2 & 2 & 2 & 2 & 2 \\
\hline 9. Clear findings & 2 & 1 & 2 & 2 & 2 & 2 & 2 & 2 & 2 & 2 & 2 & 2 \\
\hline
\end{tabular}

This article is protected by copyright. All rights reserved. 


\begin{tabular}{|l|l|l|l|l|l|l|l|l|l|l|l|l|}
\hline $\begin{array}{l}\text { 10. Value of the } \\
\text { research }\end{array}$ & 2 & 1 & 2 & 2 & 2 & 2 & 2 & 2 & 2 & 2 & 2 \\
\hline $\begin{array}{l}\text { Total scores out } \\
\text { of } 20\end{array}$ & 16 & 11 & 19 & 15 & 15 & 17 & 18 & 18 & 18 & 18 & 17 & 18 \\
\hline
\end{tabular}


Table 2: Papers included in the review

\begin{tabular}{|c|c|c|c|c|c|c|}
\hline $\begin{array}{l}\text { Study Citation } \\
\text { Country } \\
\text { Journal Impact } \\
\text { Factor }\end{array}$ & Aims & Sample & $\begin{array}{l}\text { Data collection } \\
\text { method }\end{array}$ & Key Findings & Recommendations & $\begin{array}{l}\text { CASP } \\
\text { score } \\
\text { out of } \\
20\end{array}$ \\
\hline 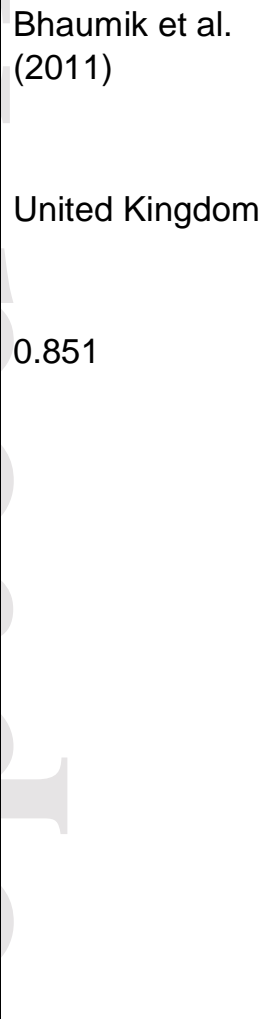 & $\begin{array}{l}1 . \quad \text { To identify } \\
\text { the numbers of } \\
\text { teenagers with } \\
\text { intellectual disabilities } \\
\text { between } 16-19 \text { years } \\
\text { and the needs and } \\
\text { perceptions of their } \\
\text { carers regarding the } \\
\text { transitions process } \\
\text { within one strategic } \\
\text { health authority in } \\
\text { England } \\
\text { 2. To map the } \\
\text { findings to the } \\
\text { achievement of } 3 \\
\text { standards of } \\
\text { transition care } \\
\text { focusing on i) } \\
\text { transition plan; ii) } \\
\text { access to health and } \\
\text { social care services; } \\
\text { iii) carer satisfaction }\end{array}$ & $\begin{array}{l}\text { Ethnically diverse } \\
\text { sample of } n=79 \\
\text { teenagers with } \\
\text { intellectual disabilities } \\
\text { ( } n=48 \text { males \& } n=31 \\
\text { females; } n=17 \text { South } \\
\text { Asian \& } 56 \text { Caucasian) } \\
\text { and } \\
24 \text { interviews with carers } \\
\text { of young people with ID } \\
\text { ( } n=16 \text { male \& } 8= \\
\text { female). }\end{array}$ & $\begin{array}{l}\text { Mixed methods design: } \\
\text { cross-sectional design } \\
\text { (postal questionnaires) } \\
\text { \& grounded theory } \\
\text { approach (qualitative } \\
\text { interviews with carers) }\end{array}$ & $\begin{array}{l}\text { Most of the young people } \\
\text { presented with significant } \\
\text { levels of intellectual } \\
\text { disability, multiple physical, } \\
\text { mental and behavioural } \\
\text { problems and required } \\
\text { supervision. A range of } \\
\text { education, health and social } \\
\text { care services were used. } \\
\text { Families reported many } \\
\text { unmet needs and difficulties } \\
\text { accessing information } \\
\text { about transitions and the } \\
\text { process and planning. } \\
\text { Achievement of standards } \\
\text { was poor: } \\
\text { i) Transition plan } \\
\text { (31\% had one in place) } \\
\text { ii) Access to health } \\
\text { and social care services }\end{array}$ & $\begin{array}{l}\text { 1. Integrated referral } \\
\text { systems for health and care } \\
\text { services need to be } \\
\text { developed. } \\
2 . \quad \text { Clear pathways of } \\
\text { care need to be in place with } \\
\text { monitoring of individual and } \\
\text { system outcomes. } \\
\text { 3. There is a need to } \\
\text { examine different healthcare } \\
\text { access patterns for South } \\
\text { Asian populations. }\end{array}$ & 18 \\
\hline
\end{tabular}

This article is protected by copyright. All rights reserved. 


\begin{tabular}{|c|c|c|c|c|c|c|c|}
\hline & & with transition & & & $\begin{array}{l}\text { (50\% reported difficulty) } \\
\text { iii) Carer satisfaction } \\
\text { with transition }(26 \%)\end{array}$ & & \\
\hline 2. & $\begin{array}{l}\begin{array}{l}\text { Camfield et al. } \\
(2011)\end{array} \\
\text { United States } \\
5.067\end{array}$ & $\begin{array}{l}\text { To identify practice } \\
\text { characteristics and } \\
\text { issues related to } \\
\text { transitioning care for } \\
\text { young people with } \\
\text { intellectual disabilities } \\
\text { and Lennox-Gastaut } \\
\text { Syndrome. }\end{array}$ & $\begin{array}{l}\text { Sample of } n=133 \\
\text { neurologists and nurse } \\
\text { delegates attending a } \\
\text { practice symposium. }\end{array}$ & $\begin{array}{l}\text { A cross-sectional } \\
\text { design: } \\
\text { Questionnaire }\end{array}$ & $\begin{array}{l}\text { There is dissatisfaction with } \\
\text { the transitions process for } \\
\text { patients with intellectual } \\
\text { disabilities. Child } \\
\text { neurologists often retain } \\
\text { adults with intellectual } \\
\text { disabilities and Lennox- } \\
\text { Gastaut Syndrome in their } \\
\text { paediatric clinic into } \\
\text { adulthood. } \\
\text { Potential influence of US } \\
\text { insurance health care } \\
\text { system in promoting } \\
\text { retention of adults in } \\
\text { paediatric services to } \\
\text { maximise financial return. } \\
\text { Paediatric and adult } \\
\text { neurology services need to } \\
\text { develop better working } \\
\text { relationships as the } \\
\text { syndrome is lifelong and } \\
\text { care on-going. }\end{array}$ & $\begin{array}{l}\text { 1. Paediatric } \\
\text { neurologists and other health } \\
\text { care professionals require } \\
\text { education and direction to } \\
\text { facilitate the transition } \\
\text { process. } \\
2 \text {. Further work is } \\
\text { required to develop optimal } \\
\text { transition models, which } \\
\text { should include transition } \\
\text { clinics. }\end{array}$ & 11 \\
\hline 3. & $\begin{array}{l}\text { Davies et al. } \\
(2011) \\
\text { Canada }\end{array}$ & $\begin{array}{l}\text { To identify the } \\
\text { perceptions of } \\
\text { transition from the } \\
\text { perspectives of } \\
\text { parents and young } \\
\text { people with }\end{array}$ & $\begin{array}{l}\text { Sample of } n=11 \text { young } \\
\text { people with intellectual } \\
\text { disabilities \& } n=17 \\
\text { parents }\end{array}$ & $\begin{array}{l}\text { Qualitative } \\
\text { interpretative design: } \\
\text { Interviews }\end{array}$ & $\begin{array}{l}\text { Parents felt a sense of } \\
\text { abandonment from their } \\
\text { paediatric health team at } \\
\text { the time of transition to } \\
\text { adult healthcare and } \\
\text { experienced a sense of }\end{array}$ & $\begin{array}{l}\text { 1. The emotional } \\
\text { impact of the transitions } \\
\text { process on parents needs to } \\
\text { be recognised and supports } \\
\text { provided. }\end{array}$ & 19 \\
\hline
\end{tabular}

This article is protected by copyright. All rights reserved. 


\begin{tabular}{|c|c|c|c|c|c|c|c|}
\hline & 0.36 & $\begin{array}{l}\text { intellectual } \\
\text { disabilities. }\end{array}$ & & & $\begin{array}{l}\text { loss, uncertainty and fear. } \\
\text { Significant gaps in care } \\
\text { provision were often } \\
\text { experienced leading to } \\
\text { poorer health outcomes. } \\
\text { There was a lack of } \\
\text { coordination within } \\
\text { healthcare systems which } \\
\text { was further complicated by } \\
\text { the range of needs of the } \\
\text { young people. The health } \\
\text { and well-being of parents } \\
\text { were compromised during } \\
\text { transition period. }\end{array}$ & $\begin{array}{l}2 . \quad \text { More guidance and } \\
\text { improved resources are } \\
\text { required to facilitate and } \\
\text { improve the transitions } \\
\text { process. } \\
\text { 3. Nurse specialists } \\
\text { should act as co-ordinators } \\
\text { within sub specialties and } \\
\text { provide expert knowledge } \\
\text { and support. }\end{array}$ & \\
\hline 4. & $\begin{array}{l}\text { Woodard et al. } \\
(2012) \\
\text { United States } \\
4.098\end{array}$ & $\begin{array}{l}\text { To assess the } \\
\text { healthcare needs of } \\
\text { young people with } \\
\text { complex health needs } \\
\text { attending a transitions } \\
\text { support programme }\end{array}$ & $\begin{array}{l}\text { Sample of } n=87 \text { parents } \\
\text { of young people with } \\
\text { complex health needs } \\
\text { and intellectual } \\
\text { disabilities ( } 17 \% \text { sample } \\
\text { had intellectual } \\
\text { disabilities) }\end{array}$ & $\begin{array}{l}\text { Cross-sectional design: } \\
\text { Questionnaire }\end{array}$ & \begin{tabular}{|l|} 
Higher health service \\
utilisation except for mental \\
health and substance use \\
services, with nearly half \\
reporting at least one \\
unmet need. Specific areas \\
of unmet need included \\
physical and speech and \\
language therapy. \\
One third of parents saw \\
the relevance of \\
anticipatory care planning \\
and resuscitation decisions; \\
two-thirds of these had not \\
had this need met.
\end{tabular} & $\begin{array}{l}\text { Transitions services are } \\
\text { required for young people } \\
\text { with complex health needs } \\
\text { and intellectual disabilities to } \\
\text { assess and identify their } \\
\text { health needs and } \\
\text { characteristics to inform the } \\
\text { design of effective patient- } \\
\text { centred services. }\end{array}$ & 15 \\
\hline 5. & Rehm et al. (2012) & $\begin{array}{l}\text { To identify the } \\
\text { transition support } \\
\text { needs of young }\end{array}$ & $\begin{array}{l}\text { Sample of } n=214 ; n=64 \\
\text { young people with } \\
\text { intellectual disabilities, }\end{array}$ & $\begin{array}{l}\text { Qualitative design: } \\
\text { Interpretive field design }\end{array}$ & $\begin{array}{l}\text { Study linked to US medical } \\
\text { consensus statement on } \\
\text { transitions for young adults }\end{array}$ & $\begin{array}{l}\text { 1. Effective transitions } \\
\text { extend beyond placing and } \\
\text { locating within adult health }\end{array}$ & 14 \\
\hline
\end{tabular}

This article is protected by copyright. All rights reserved. 


\begin{tabular}{|c|c|c|c|c|c|c|c|}
\hline & $\begin{array}{l}\text { United States } \\
0.822\end{array}$ & $\begin{array}{l}\text { people with } \\
\text { intellectual disabilities }\end{array}$ & $\begin{array}{l}n=77 \text { parents, } n=27 \text { care } \\
\text { providers } \& n=46 \text { special } \\
\text { education teachers. }\end{array}$ & - ethnography & \begin{tabular}{|l|} 
with special health care \\
needs. \\
Participants want to enable \\
young people with \\
intellectual disabilities to \\
function as independently \\
as possible as they \\
transition into adulthood; \\
transition priorities include \\
health protection, health \\
maintenance, promoting \\
personal safety, meaningful \\
education and employment \\
post-school and safe social \\
opportunities
\end{tabular} & $\begin{array}{l}\text { services, with a need to } \\
\text { respond to wider needs } \\
\text { including meaningful post- } \\
\text { school activities and social } \\
\text { opportunities. } \\
2 \quad \quad \text { Nurses need to } \\
\text { contribute to life-course } \\
\text { planning that is } \\
\text { comprehensive and holistic. }\end{array}$ & \\
\hline 7. & $\begin{array}{l}\text { Barron et al. } \\
(2013) \\
\text { United Kingdom } \\
2.039\end{array}$ & $\begin{array}{l}\text { To examine the } \\
\text { socio-economic and } \\
\text { clinical characteristics } \\
\text { and patterns of } \\
\text { service use and } \\
\text { associated costs of } \\
\text { young people with } \\
\text { intellectual disabilities } \\
\text { and challenging } \\
\text { behaviours } \\
\text { transitioning to adult } \\
\text { services. }\end{array}$ & $\begin{array}{l}\text { Sample of } n=27 \text { people } \\
\text { with intellectual } \\
\text { disabilities and } \\
\text { challenging behaviour. }\end{array}$ & $\begin{array}{l}\text { Cross-sectional design: } \\
\text { Demographic data and } \\
4 \text { questionnaires - } \\
\text { Strengths \& Difficulties } \\
\text { Questionnaire; Mini } \\
\text { PAS-ADD; Client } \\
\text { Service Receipt } \\
\text { Inventory \& Challenging } \\
\text { Behaviour Checklist. }\end{array}$ & $\begin{array}{l}\text { All participants with } \\
\text { intellectual disabilities had } \\
\text { challenging behaviour, } 23 \text { a } \\
\text { mental health diagnosis } \\
\text { and } 18 \text { a physical health } \\
\text { diagnosis. There is no } \\
\text { correlation between } \\
\text { challenging behaviour and } \\
\text { cost of care. Informal care } \\
\text { accounts for } 66 \% \text { of total } \\
\text { cost of care. Transitions } \\
\text { outcomes and associated } \\
\text { costs in lacking. }\end{array}$ & $\begin{array}{l}\text { Further research is required } \\
\text { to guide the commissioning } \\
\text { of appropriate services to } \\
\text { enable transitions and } \\
\text { outcomes achieved. }\end{array}$ & 17 \\
\hline 7. & $\begin{array}{l}\text { Bindels-de Heus et } \\
\text { al. (2013) }\end{array}$ & $\begin{array}{l}\text { To identify the } \\
\text { experiences of } \\
\text { parents of young } \\
\text { people between 16- }\end{array}$ & $\begin{array}{l}\text { Sample of } n=131 \text { parents } \\
\text { of young people with } \\
\text { PIMD. }\end{array}$ & $\begin{array}{l}\text { Cross-sectional design: } \\
\text { web-based } \\
\text { questionnaire }\end{array}$ & $\begin{array}{l}22 \% \text { of the young people } \\
\text { remained in paediatric care. } \\
22 \% \text { had no care } \\
\text { coordinator. Parents value }\end{array}$ & $\begin{array}{l}\text { 1. Recommendations } \\
\text { for parents, paediatricians } \\
\text { and adult specialists. }\end{array}$ & 18 \\
\hline
\end{tabular}

This article is protected by copyright. All rights reserved. 


\begin{tabular}{|c|c|c|c|c|c|c|c|}
\hline & $\begin{array}{l}\text { The Netherlands } \\
1.176\end{array}$ & $\begin{array}{l}26 \text { years of age with } \\
\text { profound intellectual } \\
\text { and multiple } \\
\text { disabilities (PIMD) of } \\
\text { the transfer from } \\
\text { paediatric to adult } \\
\text { medical care. }\end{array}$ & & & $\begin{array}{l}\text { the care and support } \\
\text { provided by paediatricians } \\
\text { and wanted it to continue. } \\
\text { They were critical of their } \\
\text { preparation for the } \\
\text { transition. }\end{array}$ & $\begin{array}{l}\text { 2. The transitioning } \\
\text { process should to start at an } \\
\text { early stage with provision of } \\
\text { information about what is } \\
\text { involved. } \\
\text { 3. Joint consultation } \\
\text { clinics between paediatric } \\
\text { and adult health services are } \\
\text { recommended to improve } \\
\text { coordination, communication } \\
\text { and information sharing. }\end{array}$ & \\
\hline 8. & $\begin{array}{l}\text { Jensen \& Davis } \\
(2013) \\
\text { United States } \\
2.026\end{array}$ & $\begin{array}{l}\text { To identify patterns of } \\
\text { healthcare transitions } \\
\text { for adults with Down } \\
\text { syndrome. }\end{array}$ & $\begin{array}{l}\text { Sample of } n=205 \text { adults } \\
\text { with Down syndrome } \\
\text { aged } 18-45 \text { years } \\
\text { receiving institutional } \\
\text { care between } 2000- \\
2008 \text {. }\end{array}$ & $\begin{array}{l}\text { Longitudinal, } \\
\text { observational cohort } \\
\text { design of administrative } \\
\text { data from health } \\
\text { records }\end{array}$ & $\begin{array}{l}52 \% \text { of the total sample had } \\
\text { not fully transitioned into } \\
\text { adult healthcare. Those } \\
\text { patients continued to } \\
\text { receive 'mixed' care } \\
\text { between adult and child } \\
\text { services, often with } \\
\text { subspecialty involvement. } \\
\text { Higher healthcare costs } \\
\text { were incurred by patients in } \\
\text { 'mixed' child and adult } \\
\text { healthcare. }\end{array}$ & $\begin{array}{l}\text { 1. Existing transition } \\
\text { guidelines should be } \\
\text { adapted to ensure the most } \\
\text { clinically appropriate care, } \\
\text { whether this takes place in } \\
\text { adult or paediatric } \\
\text { specialties. } \\
\text { 2. Future studies } \\
\text { should consider the } \\
\text { implications of care delivery } \\
\text { on clinical outcomes. }\end{array}$ & 18 \\
\hline 9. & $\begin{array}{l}\text { Kuchenbuch et al. } \\
(2013) \\
\text { France } \\
2.6\end{array}$ & $\begin{array}{l}\text { To identify the } \\
\text { perceptions of } \\
\text { transitioning from } \\
\text { paediatric to adult } \\
\text { health services }\end{array}$ & $\begin{array}{l}\text { Sample of } n=51 \text { families } \\
\text { of young people with } \\
\text { Dravet syndrome }\end{array}$ & $\begin{array}{l}\text { Cross-sectional design: } \\
\text { postal questionnaire }\end{array}$ & $\begin{array}{l}61 \% \text { of the sample had } \\
\text { transtioned from child } \\
\text { neurology to adult health } \\
\text { services. Satisfaction with } \\
\text { the transition process was } \\
\text { influenced by the length of } \\
\text { follow-up by paediatric } \\
\text { neurologist, transitioning } \\
\text { after } 18 \text { yesrs of age and }\end{array}$ & $\begin{array}{l}1 . \quad \text { Young people with } \\
\text { ID and severe epilepsy need } \\
\text { to transition at } 18 \text { years of } \\
\text { age to adult services } \\
2 \quad \quad \text { The transition } \\
\text { process needs to include } \\
\text { one follow up appointment } \\
\text { within paediatric neurology. }\end{array}$ & 18 \\
\hline
\end{tabular}

This article is protected by copyright. All rights reserved. 


\begin{tabular}{|c|c|c|c|c|c|c|c|}
\hline & & & & & $\begin{array}{l}\text { stability of condition before } \\
\text { transitioning. The } \\
\text { experience of this group of } \\
\text { young people influenced by } \\
\text { specific nature of syndrome } \\
\text { and specialist adult } \\
\text { neurology services. }\end{array}$ & & \\
\hline 10. & $\begin{array}{l}\text { Schultz (2013) } \\
\text { United States } \\
1.450\end{array}$ & $\begin{array}{l}\text { To identify how } \\
\text { parents of } \\
\text { adolescents with } \\
\text { epilepsy and } \\
\text { cognitive impairment } \\
\text { transition to adult } \\
\text { healthcare }\end{array}$ & $\begin{array}{l}\text { Sample of } n=14 ; \\
\text { Parents }(n=7) \\
\text { Adolescents }(n=7)\end{array}$ & $\begin{array}{l}\text { Grounded theory } \\
\text { design: qualitative } \\
\text { interviews }\end{array}$ & $\begin{array}{l}\text { Transitioning can present } \\
\text { challenges with a need for } \\
\text { effective planning to } \\
\text { address the emotional } \\
\text { impact of the experience. } \\
\text { Important advocacy role for } \\
\text { parents but lack of } \\
\text { information available. } \\
\text { Feelings of uncertainty and } \\
\text { loss. }\end{array}$ & $\begin{array}{l}\text { 1. Needs effective } \\
\text { planning within a } \\
\text { transitioning programme. } \\
\text { 2. More information is } \\
\text { required by families and } \\
\text { young people. }\end{array}$ & 18 \\
\hline 11. & $\begin{array}{l}\text { Okumura et al. } \\
(2015) \\
\text { United States } \\
1.8\end{array}$ & $\begin{array}{l}\text { To develop a } \\
\text { theoretical } \\
\text { understnding of how } \\
\text { families, health care } \\
\text { providers and } \\
\text { community supports } \\
\text { assist the transition to } \\
\text { adult healthcare }\end{array}$ & $\begin{array}{l}\text { Sample of } n=41 ; \\
\text { Parents }(n=9) \\
\text { Health care providers } \\
(n=12) \\
\text { Community service } \\
\text { providers }(n=7) \\
\text { Youths }(n=13)\end{array}$ & $\begin{array}{l}\text { Grounded theory } \\
\text { design: qualitative } \\
\text { interviews }\end{array}$ & $\begin{array}{l}\text { Conflict between parents, } \\
\text { healthcare providers and } \\
\text { young people. Challenges } \\
\text { around getting resources, } \\
\text { poor planning and } \\
\text { preparation for } \\
\text { transitioning. Lack of } \\
\text { medical knowledge. } \\
\text { Theoretical framework of } \\
\text { healthcare advocacy } \\
\text { developed. }\end{array}$ & $\begin{array}{l}\text { Strong and effective } \\
\text { healthcare advocacy skills } \\
\text { are required for the transition } \\
\text { to adult healthcare. }\end{array}$ & 17 \\
\hline 12 & $\begin{array}{l}\text { Young-Southward } \\
\text { et }\end{array}$ & $\begin{array}{l}\text { A cross-sectional } \\
\text { analysis of physical }\end{array}$ & Sample & $\begin{array}{l}\text { A cross-sectional } \\
\text { design: National }\end{array}$ & $\begin{array}{l}\text { Young people with } \\
\text { intellectual disabilities were }\end{array}$ & $\begin{array}{l}1 . \quad \text { Essential to } \\
\text { recognise that young people }\end{array}$ & 18 \\
\hline
\end{tabular}

This article is protected by copyright. All rights reserved. 


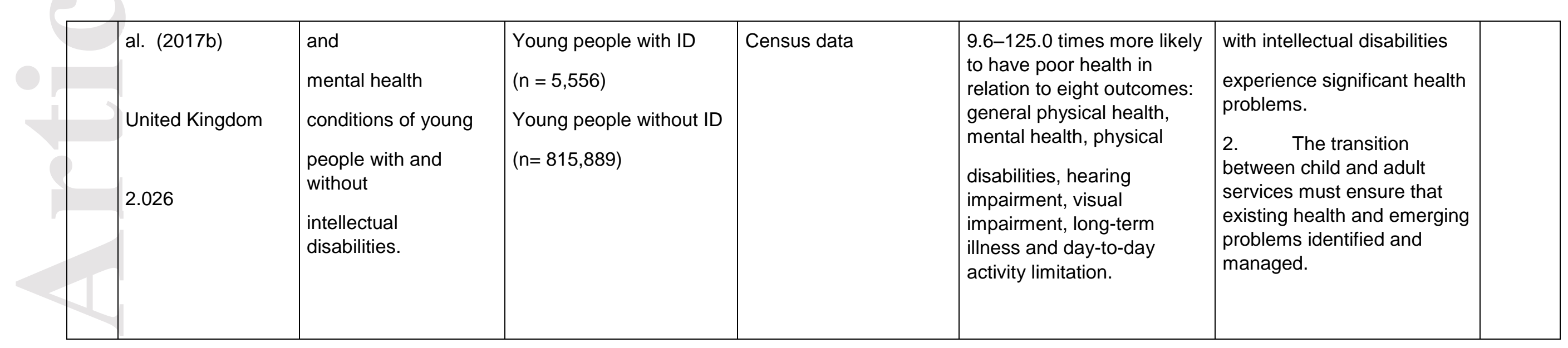

This article is protected by copyright. All rights reserved. 
Figure 1: PRISMA flowchart of systematic review process

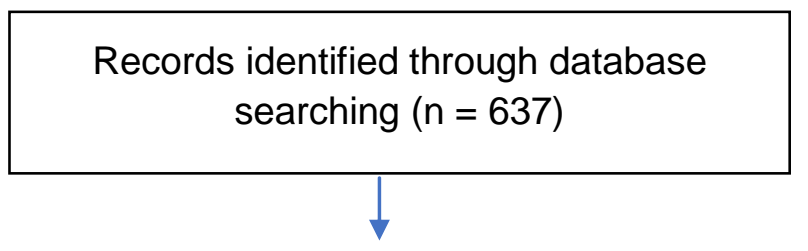

Records identified through other sources $(n=1)$

Primary exclusion of articles not focusing on the review aims, not in English, no full text available \& removal of duplicates $(n=559)$
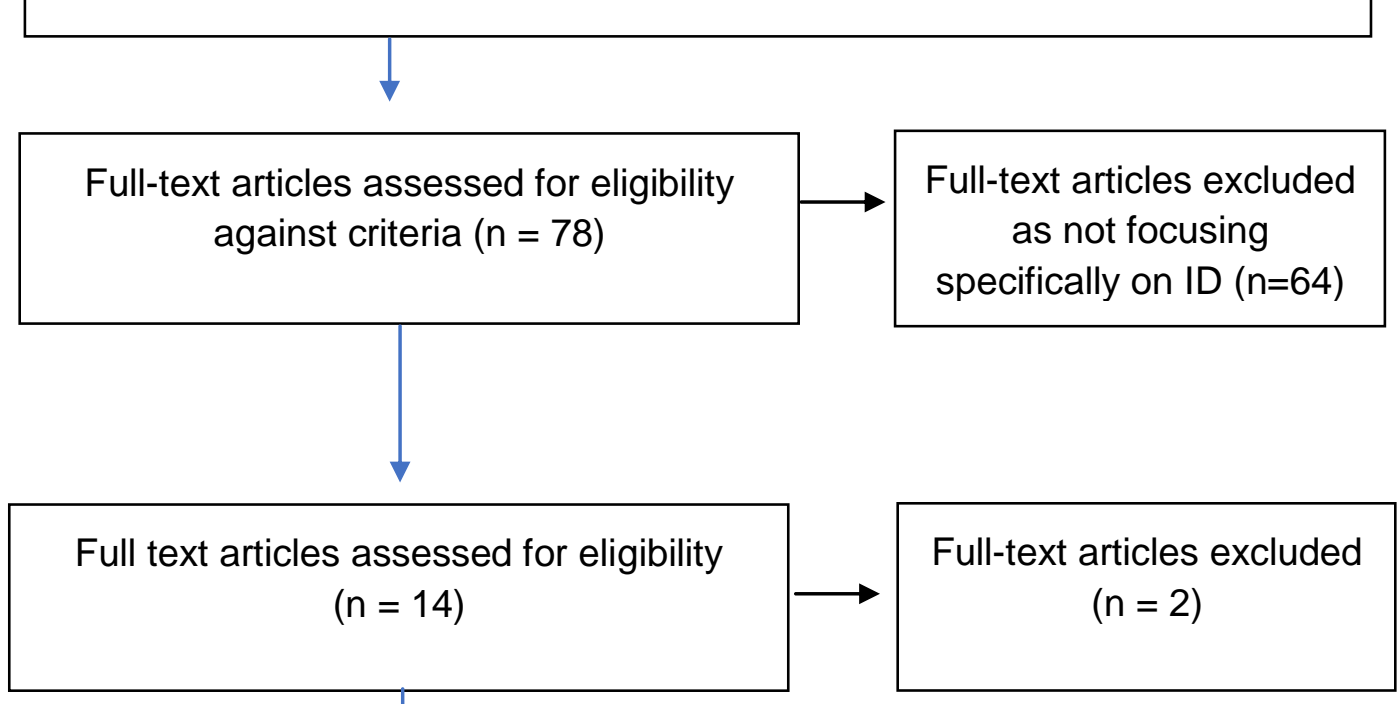

Studies included in synthesis

$(n=12)$

This article is protected by copyright. All rights reserved. 